\title{
Pengaruh Kualitas Pelaporan Keuangandan Sustainability Reporting Pada Efisiensi Investasi
}

\section{Ni Putu Lisna Vitriani ${ }^{1}$ I G A N Budiasih ${ }^{2}$}

\author{
${ }^{1,2}$ Fakultas Ekonomi dan Bisnis Universitas Udayana (Unud), Bali, Indonesia \\ e-mail:lisna_vitriani@yahoo.com
}

\begin{abstract}
ABSTRAK
Tujuan penelitian ini untuk mendapatkan bukti empiris mengenai pengaruh kualitaspelaporankeuangan dan Sustainability Reporting pada efisiensiinvestasi. Penelitian ini dilakukan pada seluruh perusahaan non keuangan yang terdaftar di Bursa Efek Indonesia tahun 2015-2017. Teknik pengambilan sampel yang digunakan dalam penelitian ini adalah teknik purposive sampling. Sampel yang diambil sebanyak 16 perusahaan dengan jumlah sampel amatan penelitian sebanyak 48 dalam 3 tahun.Teknik analisis data yang digunakan adalah Regresi Linier Berganda. Berdasarkan hasil penelitian diketahui bahwa semakin tinggi kualitas pelaporan keuangan suatu perusahaan maka semakin tinggi tingkat efisiensi investasi perusahaan tersebut serta diketahui bahwa Sustainability Reporting tidak berpengaruh pada efisiensi investasi perusahaan. Hasil penelitian ini merupakan pengamalan dari teori stakeholder dan teori keagenan yang dilakukan oleh pihak perusahaan untuk menjaga keberlangsungan operasional perusahaan jangka Panjang.

Kata kunci: Kualitas pelaporan keuangan, Sustainability Reporting, efisiensi investasi.
\end{abstract}

\begin{abstract}
The purpose of this study is to obtain empirical evidence regarding the effec of financial reporting quality and Sustainability Reporting on investment efficiency. This research was conducted on all non-financial companies listed on the Indonesia Stock Exchange in 20152017. The sampling technique used in this study was a purposive sampling. The samples taken were 16 companies with a total sample observation of 48 in 3 years. The data analysis technique used is Multiple Linear Regression. Based on the results of the study it is known that the higher the financial reporting quality of a company, the higher the level of efficiency of the company's investment and it is known that Sustainability Reporting has no effect on the efficiency of the company's investment. The results of this study are the practice of stakeholder theory and agency theory carried out by the company to maintain the long-term operational sustainability of the company.

Keywords: Financial reporting quality, Sustainability Reporting, investment efficiency.
\end{abstract}

\section{PENDAHULUAN}

Perusahaan merupakan suatu lembaga dalam bentuk organisasi yang dioperasikan untuk menyediakan barang dan jasa bagi masyarakat. Setiap perusahaan yang beroperasi pasti memiliki tujuan yang jelas dalam menjalankan operasi usahanya. Tujuan utama yang ingin dicapai oleh semua perusahaan adalah memperoleh 
Ni Putu Lisna Vitriani dan I G A N Budiasih. Pengaruh ...

keuntungan yang sebesar-besarnya untuk dapat memajukan perusahaannya dalam jangka panjang. Untuk dapat memajukan perusahaannya dalam jangka panjang, biasanya seorang manajer akan mengambil suatu keputusan untuk berinvestasi. Seorang manajer akan berupaya untuk dapat melakukan investasi dengan baik dan efisien agar tujuan memanjukan perusahaan dapat tercapai dengan baik.

Efisiensi merupakan suatu tindakan untuk menggunakan sumber daya secara tepat guna agar tidak terjadi pemborosan sumber daya yang ada. Perusahaan melakukan efisiensi dalam operasinya untuk menekan biaya dan memudahkan proses pengelolaan perusahaan agar dapat mencapai tujuan perusahaan dengan mudah. Kegiatan investasi yang dilakukan perusahaan haruslah efisien agar mendatangkan manfaat bagi perusahaan. Efisiensi investasi merupakan tingkat investasi optimal dari perusahaan, dimana investasi tersebut merupakan jenis investasi yang menguntungkan bagi perusahaan.

Tahun 2015 terjadi penurunan pendapatan yang dialami oleh 2 sektor besar dari 8 sektor perusahaan di BEI yang menjadi sampel dari penelitian ini. Pada sektor manufaktur mengalami penurunan pendapatan sebesar 0,71 persen. Penurunan pendapatan tersebut dipengaruhi oleh regulasi pemerintah. Penurunan pendapatan pada sektor manufaktur dialami oleh beberapa industri. Industri yang mengalami penurunan terbesar yaitu dialami oleh industri pengolahan tembakau yakni sebesar 58,34 persen, diikuti oleh industri karet dan plastic minus 7,7 persen. Selanjutnya dialami oleh industri bukan logam sebesar 6,64 persen, diikuti oleh industri peralatan listrik sebesar 4,74 persen, industri kayu non furniture minus 4,38 persen (www.cnnindonesia.com). 
Sektor pertambangan juga mengalami penurunan pendapatan pada tahun 2015. Kinerja perusahaan tambang batu bara paling menjadi sorotan karena dinilai masih suram. Sektor batu bara diatur oleh pemerintah. Potensi perubahan kebijakan seperti larangan ekspor, biaya royalti yang lebih tinggi dan pengendalian produksi bisa merugikan pendapatan penambang batu bara. Contoh perusahaan yang mengalami penurunan pendapatan adalah PT Indika Energy Tbk (INDY) mengalami penurunan pendapatan sebesar US\$ 7,86 juta di bandingkan tahun sebelumnya. PT Bukit Asam Tbk juga mengalami penurunan pendapatan sebesar Rp. 795,6 miliar dibandingkn tahun sebelumnya. PT United Tractors Tbk (UNTR) mengalami penurunan pendapatan sebesar 9 persen dibanding pendapatan pada tahun 2014. PT Pamapersada Nusantara (PAMA) yang merupakan anak perusahaan United Tractors dibidang jasa penambangan batu bara juga mengalami penurunan pendapatan sebesar 18 persen dibandingkan tahun sebelumnya. PT Adaro Energy Tbk mencatat penurunan pendapatan sebesar 17 persen dibandingkan pendapatan tahun 2014 (https://www.cnnindonesia.com).

Sektor semen pada tahun 2015 tercatat paling buruk dalam 4 tahun terakhir disebabkan perlambatan pertumbuhan ekonomi dan ketatnya persaingan. Berdasarkan kalkulasi bisnis, total laba bersih dari empat perusahaan semen yaitu PT Semen Indonesia (Persero) Tbk., PT Semen Baturaja (Persero) Tbk., PT Indocement Tunggal Prakarsa (Persero) Tbk. dan PT Holcim Indonesia Tbk. mencapai Rp9,4 triliun pada 2015.Kinerja secara keseluruhan empat emiten itu mengalami penurunan 20,59 persen dibandingkan dengan pertumbuhan 1,73 persen (2014), 3,45 persen (2013) dan 27,38 persen (2012). Dari 4 perusahaan itu, 
semua perusahaan mengalami penurunan laba bersih. Penguasa pangsa pasar semen di Indonesia, Semen Indonesia, membukukan laba bersih Rp 4,52 triliun pada 2015 atau turun 18,68 persen dibandingkan dengan Rp 5,55 triliun pada 2014. Penurunan laba bersih paling tajam dibukukan oleh Holcim Indonesia sebesar 73,46 persen. Penurunan kinerja tersebut turut dipengaruhi oleh lesunya volume penjualan sepanjang 2015 di tengah rencana pemerintah meningkatkan pembangunan infrastruktur fisik di sebagian wilayah Nusantara. Penurunan terjadi karena regulasi pemerintah. Hal tersebut sangat mempengaruhi tingkat efisiensi investasi perusahaan tersebut. Tiga emiten penguasa pasar semen yakni Semen Indonesia, Indocement dan Holcim mengalami perlambatan penjualan semen. Berdasarkan pendapatan atau penjualan perusahaan, Indocement membukukan pendapatan neto Rp17,79 triliun pada 2015 atau turun 10,99 persen dibandingkan dengan Rp19,99 triliun pada 2014. Penurunan juga dialami oleh Semen Indonesia dan Holcim (http://market.bisnis.com).

Tahun 2016 merupakan tahun dimana 9 sektor perusahaan di BEI mengalami penurunan pendapatan. Sektor konsumen mengalami penurunan dialami salah satunya oleh perusahaan PT Kimia Farma Tbk (KAEF) dan PT Darya-Varia Laboratoria Tbk (UNVR), masing-masing mengalami penurunan pendapatan sebesar 5 persen. Selain dua emiten farmasi tersebut, performa PT Unilever Indonesia Tbk (UNVR) juga menurun 1 persen, dari Rp. 1.590 miliar pada kuartal I 2015 menjadi Rp. 1.570 miliar. Penurunan laba juga terjadi pada sektor Perdagangan, Jasa dan Investasi yaitu salah satunya terjadi pada PT United Tractors Tbk (UNTR), dari RP. 1.640 miliar menjadi Rp. 730 miliar. Pada sektor 
Industri Dasar dan Kimia penurunan laba salah satunya dialami PT Semen Baturaja (Persero) Tbk (SMGR) sebesar 64 persen, menjadi Rp. 26,8 miliar pada Kuartal I 2016. PT Sepatu Bata Tbk (BATA) merupakan salah satu perusahaan dari sektor Aneka Industri yang mengalami penurunan laba sebesar 25 persen. Pada Kuartal I 2015 laba masih sebesar Rp. 586 juta, lalu anjlok menjadi Rp. 442 juta pada Kuartal I 2016. Anjloknya laba mencapai 90 persen dibandingkan laba pada Kuartal I 2015, terjadi pada PT Nusa Konstruksi Enjiniring (DGIK) yang merupakan salah satu perusahaan dari sektor Properti dan Konstruksi. Laba PT Harum Energy Tbk (HRUM) yang merupakan perusahaan sektor Tambang dan Energi merosot 24 persen menjadi US\$1,3 juta. Sektor Infrastruktur dan Transportasi mengalami kerugian sebesar US\$ 4,85 juta yaitu sebesar 42 persen pada Kuartal I 2016 terjadi pada PT Indika Energy Tbk (INDY). Pada sektor Agrikultur mengalami kemerosotan laba terdalam mencapai minus 67 persen, dari Rp. 153 miliar di Kuartal I 2015 menjadi Rp. 50,4 miliar pada Kuartal I tahun 2016 terjadi pada PT PP London Sumatra Indonesia Tbk (LSIP) (www.bareksa.com ).

Tahun 2017 terdapat 3 sektor besar perusahaan yang terdaftar di BEI mengalami penurunan pendapatan, hal tersebut bedampak pada tingkat efisiensi investasi perusahaan tersebut. Bank Indonesia (BI) menyoroti rendahnya pertumbuhan industri manufaktur pada kuartal I 2017. Badan Pusat Statistik (BPS) melansir, industri manufaktur sepanjang Januari-Maret 2017 hanya tumbuh 4,21 persen dibandingkan periode yang sama tahun lalu. Realisasi itu lebih lambat dari pencapaian kuartal I 2016 yang sebesar 4,59 persen. Deputi Gubernur Senior 
BI Mirza Adityaswara menuturkan industri manufaktur tumbuh 4,21 persen itu terlalu rendah untuk ekonomi Indonesia, mengingat kontribusi industri manufaktur terhadap perekonomian merupakan yang terbesar. Selain sektor manufaktur, Mirza juga menyoroti pertumbuhan sektor perdagangan yang dianggap masih belum memuaskan. Tercatat, sepanjang kuartal I 2017, sektor perdagangan hanya bisa merangkak 4,77 persen sedangkan pada tahun sebelumnya sektor perdagangan bisa tumbuh hingga 6 persen. Sektor kontruksi juga mengalami penurunan pendapatan yaitu dari 7,87 persen pada tahun lalu menjadi 6,26 pada tahun 2017 (www.cnnindonesia.com).

Berdasarkan penelitian Biddle et al.(2009) \& Biddle \& Hilary (2006)f aktor yang mempengaruhi efisiensi investasi, yaitu kualitas pelaporan keuangan. Pada penelitian ini peneliti menambahkan 1 variabel baru untuk menguji efisiensi investasi yaitu Sustainability Reporting. Salah satu yang mempengaruhi efisiensi investasi adalah kualitas dari pelaporan keuangan yang dimiliki oleh suatu perusahaan. Beberapa penelitian telah dilakukan terkait hubungan antara kualitas pelaporan keuangan dengan efisiensi investasi, menunjukkan bahwa kualitas pelaporan keuangan yang tinggi dapat meningkatkan efisiensi investasi (Biddle et al., 2009; Biddle \& Hilary, 2006). Verdi (2006) melakukan penelitian tentang pengaruh kualitas pelaporan keuangan terhadap efisiensi investasi pada level perusahaan dan menemukan bahwa kualitas pelaporan keuangan berhubungan secara positif dengan efisiensi investasi. Kesimpulan yang senada juga ditemukan Li \& Wang (2010) dan Gilaninia \& Shahram (2012). 
Chen et al. (2011) menguji peran kualitas pelaporan keuangan pada perusahaan privat di pasar modal negara berkembang, yaitu menguji sejauh mana kualitas pelaporan keuangan dapat mengurangi inefisiensi investasi. Dengan menggunakan data perusahaan dari Bank Dunia, penelitian ini menemukan bukti empiris yang menyimpulkan bahwa kualitas pelaporan keuangan berpengaruh secara positif terhadap efisiensi investasi. Kangarlouei et al. (2011) menginvestigasi hubungan antara kualitas pelaporan keuangan dan efisiensi investasi, sampel yang digunakan dalam penelitian ini berjumlah 79 perusahaan. Penelitian tersebut menyimpulkan bahwa kualitas pelaporan keuangan dan efisiensi investasi berhubungan positif dan signifikan. Selain itu, sejumlah besar literatur menunjukkan bahwa perusahaan dengan tingkat kualitas pelaporan keuangan yang lebih tinggi memiliki efisiensi investasi yang lebih tinggi, dan kualitas pelaporan keuangan efisien dalam mengurangi informasi asimetri di pasar (Biddle et al., 2009; Biddle \& Hilary, 2006; Chen et al., 2011; Gomarizet al., 2014).

Laporan keuangan adalah suatu penyajian terstruktur dari posisi keuangan dan kinerja keuangan suatu entitas. Tujuan dari laporan keuangan adalah memberikan informasi mengenai posisi keuangan, kinerja keuangan, dan arus kas entitas yang bermanfaat bagi sebagian besar kalangan pengguna laporan dalam pembuatan keputusan ekonomi. Laporan keuangan juga menunjukkan hasil pertanggungjawaban manajemen atas penggunaan sumber daya yang dipercayakan kepada mereka (IAI, 2012). Pelaporan keuangan merupakan bagian yang tidak terpisahkan dari aktivitas perusahaan. Kegiatan ini dilakukan dengan 
Ni Putu Lisna Vitriani dan I G A N Budiasih. Pengaruh ...

tujuan menghasilkan laporan keuangan yang akan digunakan pengguna sebagai bahan bagi pengambilan keputusan. Pengguna tersebut meliputi pemilik (investor) dan calon investor, kreditur dan pihak-pihak lain yang memiliki kepentingan terhadap perusahaan. Adapun jenis keputusan yang akan diambil terutama keputusan tentang investasi, kredit dan yang terkait dengan keduannya (Gilaninia \& Shahram, 2012).

Kualitas pelaporan keuangan merupakan hal yang sangat penting bagi para pemangku kepentingan secara keseluruhan. Salah satunya terkait efisiensi investasi. Kualitas pelaporan keuangan juga berdampak pada kinerja atas kegiatan tertentu perusahaan. Dalam penelitian Shehu \& Hasan (2012), karakteristik perusahaan digolongkan dalam tiga variabel yaitu struktur perusahaan (firm structure), monitoring perusahaan (firm monitoring) dan kinerja perusahaan (firm performance). Semakin tinggi kualitas pelaporan keuangan, maka informasi perusahaan semakin terefleksikan dengan baik dalam laporan keuangan tersebut sehingga asimetri informasi yang terjadi akan semakin kecil. Kondisi ini dapat membantu pengambilan keputusan investasi perusahaan menjadi lebih efisien.

Selain kualitas pelaporan keuangan, dalam penelitian ini juga menguji pengaruh Sustainability Reporting pada efisiensi investasi. Sustainability Reporting adalah laporan berkelanjutan yang dikeluarkan oleh sebuah perusahaan atau organisasi tentang dampak ekonomi, lingkungan dan sosial yang disebabkan oleh aktivitas sehari-hari. Sustainability Reporting membantu organisasi untuk mengukur dan memahami kinerja ekonomi, lingkungan, dan sosial mereka, dan kemudian menetapkan tujuan, serta mengelola perubahan secara lebih efektif. 
Sustainability Reporting atau pelaporan tanggung jawab sosial perusahaan merupakan faktor lain yang perlu dipertimbangkan oleh perusahaan dalam upaya meningkatkan citra perusahaan. Pada saat beroperasi seringkali perusahaan mengabaikan dampak sosial dan lingkungan yang timbul dari aktivitas atau tindakan ekonomi perusahaan padahal kegiatan operasi yang dilakukan perusahaan berpotensi menimbulkan kerusakan terhadap lingkungan sekitarnya. Perubahan yang ditimbulkan perusahaan dapat memunculkan kesadaran baru yaitu kesadaran akan pentingnya melakukan Sustainability Reporting oleh perusahaan. Selain itu, dorongan perusahaan untuk melaksanakan $S R$ adalah karena adanya Undang-undang Nomor 40 Tahun 2007 tentang perseroan terbatas , Pasal 74 ayat 1. Undang-undang tersebut menyebutkan bahwa "Perseroan yang menjalankan kegiatan usahanya di bidang dan/atau berkaitan dengan sumber daya alam wajib melaksanakan tanggung jawab sosial dan lingkungan”. Sustainability Reporting dapat dianggap sinonim dengan istilah pelaporan non-keuangan, triple bottom line reporting, pelaporan CSR, dan sebagainya.

Perkembangan kesadaran perusahaan untuk melakukan CSR menyebabkan perusahaan mulai menyadari untuk mengungkapkan sebuah laporan yang tidak hanya berpijak pada single bottom line, yaitu kondisi keuangan perusahaan saja tetapi berpijak pada triple bottom line, yaitu selain informasi keuangan juga menyediakan informasi sosial dan lingkungan. Pengungkapan tanggung jawab sosial (SR) perusahan adalah konsekuensi dari implementasi Good Corporate Governance untuk memperhatikan kepentingan stakeholders-nya demi kelangsungan hidup jangka panjang perusahaan. 
Ni Putu Lisna Vitriani dan I G A N Budiasih. Pengaruh ...

Beberapa penelitian telah dilakukan terkait hubungan antara CSD dengan efisiensi investasi. Penelitian sebelumnya menunjukkan bahwa perusahaan CSR yang tinggi diuntungkan dari solidaritas karyawan dan loyalitas pelanggan di saat krisis keuangan (Benlemlih \& Bitar, 2014). Hung et al.(2013) menemukan bahwa perusahaan pelaporan CSR mengalami penurunan asimetri informasi. Zong Ma \& Gao (2017) menemukan bahwa hubungan signifikan antara pengungkapan CSR dan efisiensi investasi untuk sampel perusahaan dengan kualitas pengungkapan keuanagn yang rendah, tetapi tidak untuk sampel perusahaan dengan kualitas pengungkapan keuangan yang tinggi. Penelitian tersebut juga menyatakan bahwa pengungkapan tanggungjawab sosisal juga berkontribusi untuk peningkatan efisisensi investasi.

Seluruh perusahaan non keuangan yang terdaftar di BEI dipilih sebagai populasi dalam penelitian ini. Populasi penelitian tersebut dipilih karena perusahaan tersebut memiliki nilai kapitalitas yang besar sehingga perusahaan tersebut diminati oleh calon investor dan investor sebagai tempat untuk berinvestasi. Perusahaan tersebut juga lebih banyak berhubungan langsung dengan penggunaan sumber daya alam yang dapat menimbulkan kerusakan lingkungan dan membutuhkan tindakan sosial dari perusahaan yang berbeda disekitarnya. Penelitian ini menggunakan menggunakan periode waktu dari tahun 2015 - 2017. Alasan memilih periode waktu dari tahun 2015 - 2017 karena belum diteliti pada penelitian - penelitian sebelumnya dan criteria sampel yang diteliti pada penelitian ini berbeda dengan penelitian - penelitian sebelumnya serta variable dalam penelitian ini belum banyak diteliti di Indonesia. 
Motivasi dalam penelitian ini adalah menguji pengaruh Kualitas Pelaoran Keuangan dan Sustainability Reporting pada Efisiensi Investasi. Penelitian ini menggunakan seluruh perusahaan non keuangan yang terdaftar di Bursa Efek Indonesia tahun 2015-2017 karena ada fenomena yang terjadi pada tahun 2015 sampai tahun 2017 yaitu kinerja keuangan perusahaan non keuangan mengalami penurunan yang disebabkan oleh menurunnya harga komoditas dan rencana peraturan pemerintah. Hal ini tentunya akan mempengaruhi efisiensi investasi yang dilakukan perusahaan dengan melihat bagaimana kualitas pelaporan keuangan serta pelaporan $S R$ yang dilakukan perusahaan. Adanya fenomena tersebut serta belum banyak yang meneliti maka penelitian dengan topik efisiensi investasi menarik untuk dilakukan.

Pelaporan keuangan dituntut untuk menyediakan informasi yang berguna untuk investor, kreditur, serta pengguna lainnya dalam melakukan investasi yang rasional, keputusan kredit, dan keputusan lain yang serupa (Whiteet al., 2003). Hal tersebut sesuai dengan teori stakeholder yang mana perusahaan mempunyai dorongan untuk memberikan informasi kepada semua pihak yang memiliki kepentingan dalam perusahaan. Namun demikian, dalam kegiatan perusahaan, terdapat kemungkinan manajer akan melakukan investasi yang tidak selaras dengan tujuan para pemegang saham (Jensen \& Meckling, 1976). Manajer akan cenderung meningkatkan kemakmuran pribadinya di atas kemakmuran pemegang saham. Adanya asimetri informasi antara manajer dan investor (penyedia modal) yang terdiri dari moral hazard dan adverse selection dapat menurunkan efisiensi investasi dikarenakan kurangnyainformasi yang transparan dan akurat. 
Penelitian sebelumnya menunjukkan bahwa kualitas pelaporan keuangan yang tinggi dapat meningkatkan efisiensi investasi (misalnya, Biddle \& Hilary, 2006; Biddle et al., 2009). Verdi (2006) melakukan penelitian tentang pengaruh kualitas pelaporan keuangan terhadap efisiensi investasi pada level perusahaan dan menemukan bahwa kualitas pelaporan keuangan berhubungan secara positif dengan efisiensi investasi. Kesimpulan yang senada juga ditemukan Li \& Wang (2010)dan Gilaninia \& Shahram (2012).Chen et al.(2011)menguji peran kualitas pelaporan keuangan pada perusahaan privat di pasar modal negara berkembang, yaitu menguji sejauh mana kualitas pelaporan keuangan dapat mengurangi inefisiensi investasi. Dengan menggunakan data perusahaan dari Bank Dunia, penelitian ini menemukan bukti empiris yang menyimpulkan bahwa kualitas pelaporan keuangan berpengaruh secara positif terhadap efisiensi investasi. Kangarloueiet al. (2011) menginvestigasi hubungan antara kualitas pelaporan keuangan dan efisiensi investasi, sampel yang digunakan dalam penelitian ini berjumlah 79 perusahaan. Penelitian tersebut menyimpulkan bahwa kualitas pelaporan keuangan dan efisiensi investasi berhubungan positif dan signifikan.

Kualitas pelaporan keuangan yang tinggi dapat menyebabkan para pemegang saham yakin untuk berinvestasi di perusahaan tersebut. Pengungkapan informasi yang baik dalam laporan keuangan adalah salah satu cara yang harus dilakukan perusahaan untuk menjaga hubungan baik dengan para pemegang saham agar perusahaan mendapatkan citra positif serta dapat meningkatkan minat investor untuk berinvestasi. Kualitas pelaporan keuangan yang tingi dapat menarik penyedia dana dari luar sehingga berminat untuk memberikan pendanaan 
pada perusahaan. Kualitas pelaporan keuangan yang tinggi akan menurunkan diskresi manajemen dan memudahkan untuk menilai investasi yang optimal. Kualitas pelaporan yang tinggi dapat membantu manajemen dan investor dalam pengambilan keputusan. Semakin tinggi kualitas pelaporan keuangan, maka informasi perusahaan semakin terefleksikan dengan baik dalam laporan keuangan tersebut. Kondisi ini dapat membantu pengambilan keputusan investasi perusahaan menjadi lebih efisien karena semakin kecil asimetri informasi.

$\mathrm{H}_{1}$ : Kualitas Pelaporan Keuangan berpengaruh positif pada Efisiensi Investasi.

Pengungkapan Sustainability Reporting $(S R)$ ini merupakan salah satu sumber informasi yang bisa dijadikan acuan dalam melakukan keputusan investasi oleh stakeholder sesuai dengan teori stakeholder. Berdasarkan teori legitimasi dinyatakan bahwa pengungkapan $S R$ dapat berpengaruh dalam mengembangkan usahanya apabila dalam kegiatan operasinya perusahaan tersebut berjalan sesuai harapan masyarakat. $S R$ adalah suatu kegiatan sosial yang melibatkan masyarakat dan perusahaan serta kegiatan $S R$ merupakan pengamalan dari teori legitimasi untuk mempertahankan keberlangsungan hidup perusahaan. Teori legitimasi mendorong perusahaan untuk meyakinkan bahwa aktivitas dan kinerjanya dapat diterima oleh masyarakat. Sustainability Report dapat digunakan oleh perusahaan untuk membuktikan bahwa perusahaan telah menjalankan tanggungjawab sosial dan lingkungan sesuai dengan aturan yang berlaku. Hal ini sebagai upaya agar keberadaan organisasi dapat diterima oleh masyarakat. Legitimasi dari masyarakat adalah sumber daya operasional yang paling penting bagi perusahaan karena hal ini terkait dengan kelangsungan hidup perusahaan(Tarigan dkk. 2014). 
Perusahaan memiliki kontrak sosial dengan masyarakat dilingkungan bisnisnya dan melalui pengungkapan SR tersebut diharapkan perusahaan akan mendapatkan legitimasi dari masyarakat yang berdampak pada kelangsungan hidup perusahaan. Perusahaan yang sudah mendapatkan legitimasi dari masyarakat dan telah melakukan kegiatan SR dengan baik maka perusahaan tersebut akan mendapatkan citra yang positif dari masyarakat sehingga perusahaan tersebut dapat diyakini oleh investor untuk tempat berinvestasi yang efisien.

Beberapa penelitian telah dilakukan terkait hubungan antara CSR dengan efisiensi investasi. Penelitian sebelumnya menunjukkan bahwa perusahaan $C S R$ yang tinggi diuntungkan dari solidaritas karyawan dan loyalitas pelanggan di saat krisis keuangan (Benlemlih \& Bitar, 2014).Hung et al. (2013) menemukan bahwa perusahaan pelaporan CSR wajib mengalami penurunan asimetri informasi. ZongMa \& Gao (2017)menemukan bahwa hubungan signifikan antara pengungkapan $C S R$ dan efisiensi investasi untuk sampel perusahaan dengan kualitas pengungkapan keuangan yang rendah, tetapi tidak untuk sampel perusahaan dengan kualitas pengungkapan keuangan yang tinggi. Penelitian tersebut juga menyatakan bahwa pengungkapan tanggungjawab sosial juga berkontribusi untuk peningkatan efisiensi investasi. Dhaliwal dkk. (2011) secara empiris menunjukkan bahwa perusahaan $C S R$ yang tinggi mengungkapkan lebih banyak informasi tentang aktivitas keuangan dan ekstra-keuangan mereka dari perusahaan $C S R$ rendah. Dengan demikian, perusahaan $C S R$ yang tinggi cenderung mencerminkan citra positif tentang sikap mereka terhadap investor dan pemangku kepentingan. Dhaliwal et al. (2011) menyimpulkan bahwa informasi 
terkait CSR dapat berfungsi sebagai pengganti informasi keuangan, terutama ketika menyangkut mengurangi asimetri informasi antara perusahaan dan pemangku kepentingan non-keuangannya. Jika perusahaan $C S R$ tinggi dikaitkan dengan kualitas informasi yang lebih banyak, lebih banyak transparansi, dan manajemen laba yang kurang, ini harus tercermin dalam efisiensi investasi mereka. Perusahaan CSR tinggi cenderung meningkatkan efisiensi investasi perusahaan karena rendahnya asimetri informasi yang dilaporkan perusahaan.

Dorongan perusahaan untuk memberikan informasi adalah karena terdapat asimetri informasi antara perusahaan dengan pihak luar karena perusahaan mengetahui lebih banyak mengenai perusahaan dan prospek yang akan datang daripada pihak luar (investor dan kreditor). Kurangnya informasi pihak luar mengenai perusahaan menyebabkan mereka melindungi diri mereka dengan memberikan harga yang rendah untuk perusahaan. Salah satu informasi yang wajib untuk diungkapkan oleh perusahaan adalah informasi tentang tanggung jawab sosial perusahaan. Pengungkapan $S R$ pada non keuangan sampai tahun 2017 rata-rata dari tahun ke tahun cenderung menurun.

Informasi tentang pengungkapan $S R$ merupakan suatu sinyal perusahaan untuk mengkomunikasikan kinerja perusahaan dalam jangka panjang, karena $S R$ terkait dengan acceptability dan sustainability, yang artinya perusahaan diterima dan berkelanjutan untuk dijalankan disuatu lingkungan dalam jangka panjang. Pengungkapan $S R$ juga berfungsi untuk mendapatkan gambaran kedepanya bagaimana prospek perusahaan tersebut serta efisiensi investasi dari perusahaan tersebut. Sementara sinyal perusahaan berupa laba lebih mengkomunikasikan 
kinerja perusahaan untuk jangka pendek. Informasi tentang pengungkapan SR yang baik akan menyebabkan perusahaan tersebut mendapatkan nilai yang positif dari masyarakan dan investor sehingga investor efisien untuk melakukan investasi di perusahaan tersebut.

$\mathrm{H}_{2} \quad$ : Sustainability Reporting berpengaruh Positif pada Efisiensi Investasi.

\section{METODE PENELITIAN}

Lokasi Penelitian ini adalah seluruh perusahaan non keuangan yang terdaftar di Bursa Efek Indonesia (BEI) tahun 2015-2017 dengan mengakses website www.idx.com dan web resmi seluruh perusahaan non keuangan. Alasan memilih lokasi penelitian tersebut karena perusahaan-perusahaan yang terdaftar di BEI melaporkan laporan keuangan secara lengkap serta melaporkan Sustainability Report pada web resmi masing-masing perusahaan.

Efisiensi investasi dalam penelitian ini diukur dengan model yang telah dipakai olehBiddle et al. (2009) untuk memperkirakan tingkat investasi yang diharapkan perusahaan i pada tahun t berdasarkan peluang pertumbuhan yaitu diukur dengan pertumbuhan penjualan.

$$
\begin{array}{ll}
\text { Investment }_{i, t+1} & =\beta_{0^{+}}+\beta_{1} * \text { Sales Growth }_{i, t}+\varepsilon_{i, t+1} \ldots \ldots \ldots \ldots \ldots \ldots \ldots \ldots \ldots \ldots \ldots \ldots \ldots \ldots \ldots \ldots \\
\text { Investment }_{i, t+1} & =\text { Ukuran dari total keseluruhan investasi pada aktiva tetap. } \\
{\text { Sales } \text { Growth }_{i t}} & =\text { Persentase dari pertumbuhan penjualan perusahaan I dari } \\
& \mathrm{t}-1 \mathrm{ke} \mathrm{t}
\end{array}
$$

Efisiensi investasi yang diproksikan dengan menggunakan model investasi di atas nantinya akan memperoleh nilai residual yang akan digunakan sebagai 
pengukuran variabel efisiensi investasi.Nilai residual tersebut kemudian diabsolutkan, kemudian nilai absolut ini akan digunakan sebagai pengukuran efisiensi investasi.Semakin kecil nilai residual maka investasi perusahaan akan semakin efisien.

Pendapatan.diskresioner dari Mcnichols \& Stubben (2014) sebagai proksi manajemen laba.

$$
\begin{aligned}
& \Delta A R_{i, t}=\quad \beta_{0}+\beta_{1} \Delta \text { Sales }_{i, t}+\varepsilon_{i, t} \\
& \triangle A R_{i, t} \quad=\text { perubahan piutang untuk perusahaan I pada } \\
& \text { tahun } \mathrm{t} \\
& \Delta \text { Sales }_{i, t} \quad=\text { perubahan pendapatan penjualan untuk } \\
& \text { perusahaan I pada tahun } t \text {. }
\end{aligned}
$$

Pengungkapan Sustainability Reporting (SR) ini diukur dengan menggunakan indeks SRDI yang dikembangkan oleh Wijayanti \& Surakarta (2016). Indeks untuk masing-masing perusahaan dihitung sebagai berikut :

$$
S R D I=\frac{\mathrm{n}}{\mathrm{k}}
$$

Keterangan :

$$
\begin{array}{ll}
\text { SRDI } & \text { Sustainability Report Disclosure Index perusahaan } \\
\mathrm{n} & \text { jumlah item yang diungkapkan perusahaan, } \\
& \text { variabel dummy: } 1=\text { jika item diungkapkan; } 0=\text { jika } \\
& \text { item tidak diungkapkan } \\
= & \text { jumlah item yang diharapkan, } \mathrm{k} \leq 91
\end{array}
$$

Populasi dalam penelitian ini meliputi seluruh perusahaan non keuangan yang terdaftar di Bursa Efek Indonesia tahun 2015-2017. Seluruh perusahaan non keuangan digunakan sebagai sample karena pertimbangan homogenitas data. 
Ni Putu Lisna Vitriani dan I G A N Budiasih. Pengaruh ...

Analisis ini diolah menggunakan program SPSS. Teknik analisis regresi linear berganda digunakan untuk menggambarkan suatu variable terikat (dependen) dihubungkan dengan dua atau lebih veriabel bebas (independen) yaitu:

$\mathrm{Y}=\alpha+\beta_{1} \mathrm{X}_{1}+\beta_{2 .} \mathrm{X}_{2}+\varepsilon$

Keterangan :

\begin{tabular}{|c|c|}
\hline Y & $=$ Efisiensi Investasi \\
\hline$\alpha$ & $=$ nilai konstanta \\
\hline$\beta_{1}, \beta_{2}, \beta_{3}$ & $=$ Koefisien regresi variable independen \\
\hline $\mathrm{X}_{1}$ & $=$ Kualitas Pelaporan Keuangan \\
\hline $\mathrm{X}_{2}$ & $=$ Sustainability Reporting \\
\hline
\end{tabular}

\section{HASIL DAN PEMBAHASAN}

Pengujian data dalam penelitian ini menggunakan teknik analisis regresi linier berganda. Analisis ini diolah menggunakan program SPSS. Teknik analisis regresi linier berganda digunakan untuk menggambarkan suatu variabel terikat (dependen) dihubungkan dengan dua atau lebih veriabel bebas (independen). Hasil analisis regresi linier berganda dapat dilihat pada Tabel 1.

Tabel 1.

Hasil Analisis Regresi Linier Berganda

\begin{tabular}{|c|c|c|c|c|c|c|}
\hline \multirow[b]{2}{*}{ Model } & & \multicolumn{2}{|c|}{$\begin{array}{c}\text { Unstandardized } \\
\text { Coefficients }\end{array}$} & \multirow{2}{*}{$\begin{array}{c}\text { Standardized } \\
\text { Coefficients } \\
\text { Beta }\end{array}$} & \multirow[b]{2}{*}{$t$} & \multirow[b]{2}{*}{ Sig. } \\
\hline & & $B$ & $\begin{array}{c}\text { Std. } \\
\text { Error }\end{array}$ & & & \\
\hline \multirow[t]{3}{*}{1} & (Constant) & -0.319 & 0.373 & & -0.854 & 0.398 \\
\hline & $\mathrm{X} 1$ & 0.335 & 0.131 & 0.355 & 2.548 & 0.014 \\
\hline & $\mathrm{X} 2$ & 0.028 & 0.872 & 0.004 & 0.032 & 0.975 \\
\hline
\end{tabular}

Berdasarkan Tabel 1 dapat dibuat persamaan regresi linier berganda sebagai berikut:

$$
\mathrm{Y}=-0,319+0,335 \mathrm{X}_{1}+0,028 \mathrm{X}_{2}+0,373
$$


Nilai konstanta $(\alpha)$ sebesar $-0,319$ memiliki arti apabila Kualitas Pelaporan Keuangan dan Sustainability Report memiliki nilai konstan pada angka nol maka Efisiensi Investasi akan menurun sebesar 0,319 satuan. Koefisien regresi variabel kualitas pelaporan keuangan sebesar 0,335 memiliki arti apabila kualitas pelaporan keuangan meningkat satu satuan maka efisiensi investasi meningkat sebesar 0,335 satuan dengan asumsi variabel lainnya konstan. Koefisien regresi variabel SR sebesar 0,028 memiliki arti apabila pelaporan $S R$ meningkat satu satuan maka efisiensi investasi meningkat 0,028 satuan dengan asumsi variabel lainnya konstan.

Nilai koefisien determinasi adalah antar nol sampai satu $\left(0<\mathrm{R}^{2}<1\right)$. Nilai $\mathrm{R}^{2}$ yang kecil berarti kemampuan variabel-variabel independen dalam menjelaskan variasi dependen sangat terbatas. Nilai yang mendekati satu berarti variabel-variabel independen dapat memberikan hampir semua informasi yang dibutuhkan untuk menerangkan variabel dependen. Koefisien determinasi dapat dilihat melalui nilai adjusted $\mathrm{R}^{2}$. Hasil uji koefisien determinasi dapat dilihat pada Tabel 2.

Berdasarkan Table 2 dapat diamati nilai adjused $\mathrm{R}^{2}$ sebesar 0,088 berarti $8,8 \%$ perubahan (naik turun) pada efisiensi investasi yang dipengaruhi oleh kualitas pelaporan keuangan dan Sustainability Report, sementara sisanya sejumlah 91,2\% dipengaruhi oleh faktor - faktor lain diluar penelitian ini.

Kriteria penilaian dilakukan dengan membandingkan nilai signifikan $\mathrm{F}_{\text {hitung }}$ dengan nilai signifikan a. Apabila nilai signifikan $F_{\text {hitung }}$ kurang dari $=\alpha 0,05$ maka model penelitian dapat atau layak digunakan. Apabila tingkat signifikan $\mathrm{F} \leq$ 
$\alpha 0,05$, maka $\mathrm{H}_{\mathrm{i}}$ diterima dan $\mathrm{H}_{\mathrm{o}}$ ditolak. Namun, bila tingkat signifikan $\mathrm{F}>\alpha$ 0,05, maka $\mathrm{H}_{\mathrm{i}}$ ditolak dan $\mathrm{H}_{\mathrm{o}}$ diterima. Hasil uji signifikan simultan $\mathrm{F}$ dapat dilihat pada Tabel 3.

Tabel 3.

Hasil Uji Kelayakan Model ( Uji Statistik F)

\begin{tabular}{clccccc}
\hline Model & & Sum of & & & & \\
Squares & df & Mean Square & F & Sig. \\
\hline 1 & Regression & 8.807 & 2 & 4.404 & 3.258 & $0,048^{\mathrm{a}}$ \\
& Residual & 60.825 & 45 & 1.352 & & \\
& Total & 69.632 & 47 & & & \\
\hline \multicolumn{2}{l}{ Sumber: Data diolah, 2018 } & & & & &
\end{tabular}

Berdasarkan Tabel 3 diatas dapat dilihat nilai signifikan $\mathrm{F}$ yakni 0,048 kurang dari $0,05(0,048<0,05)$, ini berarti model yang digunakan pada penelitian ini adalah layak. Hasil ini memberikan makna bahwa seluruh variabel independen mampu memprediksi atau menjelaskan efisiensi investasi. Dengan kata lain kualitas pelaporan keuangan $\left(\mathrm{X}_{1}\right)$ dan $S R\left(\mathrm{X}_{2}\right)$ berpengaruh signifikan terhadap efisiensi investasi. Hal ini berarti model layak digunakan untuk analisis lebih lanjut atau dengan kata lain model dapat digunakan untuk memproyeksikan karena hasil goodness of fitnya baik dengan nilai signifikansi P value 0,048.

Berdasarkan Tabel 1 dapat dilihat bahwa kualitas pelaporan keuangan memiliki nilai $\beta_{1}$ sebesar 0,335 yang bernilai positif serta signifikansi 0,014 lebih kecil dibandingkan dengan 0,05. Artinya kualitas pelaporan keuangan berpengaruh signifikan positif terhadap efisiensi investasi, hal ini menunjukan apabila terjadi peningkatan kualitas pelaporan keuangan maka akan terjadi peningkatan pada efisiensi investasi. Maka hipotesis yang menyatakan bahwa kualitas pelaporan keuangan berpengaruh positif pada efisiensi investasi diterima. 
Berdasarkan Tabel 2 dapat dilihat bahwa $S R$ memiliki nilai $\beta_{2}$ sebesar 0,028 yang bernilai positif serta besar signifikansi 0,975 lebih besar dibandingkan dengan 0,05. Artinya $S R$ tidak berpengaruh terhadap efisiensi investasi. Maka hipotesis yang menyatakan bahwa Sustainability Report berpengaruh positif pada efisiensi investasi ditolak.

Hasil pengujian menunjukkan bahwa kualitas pelaporan keuangan berpengaruh positif pada efisiensi investasi sehingga hipotesis pertama $\left(\mathrm{H}_{1}\right)$ dalam penelitian ini diterima. Hal ini berarti semakin tinggi kualitas pelaporan keuangan suatu perusahaan maka semakin tinggi tingkat efisiensi investasi perusahaan tersebut. Kualitas pelaporan keuangan yang tinggi dapat menyebabkan para pemegang saham yakin untuk berinvestasi di perusahaan tersebut. Pengungkapan informasi yang baik dalam laporan keuangan adalah salah satu cara yang harus dilakukan perusahaan untuk menjaga hubungan baik dengan para pemegang saham agar perusahaan mendapatkan citra positif serta dapat meningkatkan minat investor untuk berinvestasi. Semakin tinggi kualitas pelaporan keuangan, maka informasi perusahaan semakin terefleksikan dengan baik dalam laporan keuangan tersebut. Kondisi ini dapat membantu pengambilan keputusan investasi perusahaan menjadi lebih efisien.

Hasil penelitian ini konsisten dengan hasil penelitian Verdi (2006) yang menunjukkan bahwa kualitas pelaporan keuangan berhubungan positif dengan efisiensi investasi. Chen et al.(2011) menemukan bukti empiris yang menyimpulkan bahwa kualitas pelaporan keuangan berpengaruh secara positif terhadap efisiensi investasi. Hasil penelitian yang sama juga ditemukanLi \& Wang 
Ni Putu Lisna Vitriani dan I G A N Budiasih. Pengaruh ...

(2010), Gilaninia \& Shahram (2012),Biddle \& Hilary (2006),Biddle et al. (2009), dan Kangarloueiet al. (2011).

Hasil penelitian ini merupakan pengamalan dari teori stakeholder yang sangat berperan penting dalam meningkatkan efisiensi investasi perusahaan. Perusahaan harus lebih mengutamakan kepentingan semua pihak yang memiliki kepentingan dalam perusahaan, baik itu investor maupun calon investor yang akan berinvestasi di perusahaan tersebut. Teori stakeholder mendorong perusahaan untuk memberikan informasi yang tepat dan sesuai dengan kenyataan yang terjadi kepada investor maupun calon investor untuk menciptakan citra perusahaan menjadi baik dan dapat diyakini menjadi tempat berinvestasi yang tepat.

Sustainability Reporting adalah komitmen dari semua perusahaan yang menjalankan bisnis dalam lingkungan masyarakat untuk secara sukarela memberikan perhatian terhadap lingkungan sosial dengan menitikberatkan pada keseimbangan antara perhatian terhadap aspek ekonomis, sosial dan lingkungan dalam operasinya. Hasil penelitian menunjukkan bahwa perubahan $S R$ tidak mampu mempengaruhi efisiensi investasi pada perusahaan non keuangan.

Sustainability Reporting sebagai wujud dari tanggung jawab perusahaan terhadap lingkungan dan wujud tanggung jawab sosial perusahaan. Pada hasil penelitian pengungkapan laporan keberlanjutan pada perusahaan non keuangan tidak direspon oleh investor sebagai pertimbangan dalam berinvestasi. Investor lebih memperhatikan kinerja keuangan perusahaan untuk digunakan sebagai bahan pertimbangan dalam membuat keputusan berinvestasi. Pengungkapan SR belum mampu menurunkan tingkat asimetri informasi pada perusahaan sehingga 
hal tersebut membuat pengungkapan $S R$ tidak mampu mempengaruhi efisiensi investasi Penelitian ini tidak mampu mengkonfirmasi teori stakeholder dimana pelaporan $S R$ belum mampu memberikan manfaat kepada stakeholder dalam membuat keputusan berinvestasi. Penelitian ini juga tidak mampu mengkonfirmasi teori legitimasi dimana pelaporan $S R$ belum mampu menciptakan citra positif perusahaan serta belum mampu menarik minat investor maupun calon investor untuk berinvestasi. Hal tersebut kemungkinan pelaporan $S R$ belum terlalu dimengerti manfaatnya oleh investor maupun calon investor di BEI untuk digunakan sebagai bahan pertimbangan membuat keputusan berinvestasi.

\section{SIMPULAN}

Kualitas pelaporan keuangan berpengaruh positif pada efisiensi investasi perusahaan non keuangan tahun 2015-2017. Hal ini berarti bahwa semakin tinggi kualitas pelaporan keuangan suatu perusahaan maka semakin tinggi tingkat efisiensi investasi perusahaan tersebut. Kualitas pelaporan keuangan yang tinggi dapat menyebabkan para pemegang saham yakin untuk berinvestasi di perusahaan tersebut.

Sustainability Reporting tidak berpengaruh pada efisiensi investasi. Hal ini berarti bahwa pengungkapan laporan keberlanjutan pada perusahaan non keuangan tidak diperhatikan oleh investor sebagai pertimbangan dalam berinvestasi.

Hasil uji t dalam penelitian ini menyatakan bahwa Sustainability Reporting tidak berpengaruh pada efisiensi investasi. Hal tersebut disebabkan 
karena kurangnya minat perusahaan untuk melaporkan Sustainability Report perusahaannya, sehingga tidak semua indikator dilaporkan dalam laporan SR.

Hasil tabulasi variabel SR dalam penelitian ini menyatakan bahwa dari 91 indikator GRI-G4 terdapat 53 indikator yang belum banyak diungkapkan oleh 16 perusahaan yang menjadi sampel dalam penelitian ini. Perusahaan disarankan untuk lebih meningkatkan pengungkapan SR agar dapat menghasilkan laporan yang akurat serta sinyal positif kepada investor. Sehingga pelaporan SR dapat digunakan sebagai bahan pertimbangan berinvestasi selain laporan kinerja keuangan perusahaan dan dapat meningkatkan efisiensi investasi perusahaan.

Hasil uji koefisien determinasi $\left(\mathrm{R}^{2}\right)$ penelitian ini yaitu sebesar 0,088 yang berarti variabel independen dalam penelitian ini mempengaruhi variabel dependen sebesar 8,8 persen dan sisanya sebesar 91,2 persen dipengaruhi oleh faktor lain sehingga terdapat variabel lain yang berpengaruh namun tidak ada dalam penelitian ini. Oleh sebab itu diharapkan penelitian selanjutnya mampu memperluas objek penelitian dengan cara menambah beberapa variabel independen lain atau menemukan variabel independen yang tepat dalam penelitian.

\section{REFERENSI}

Benlemlih, M., \& Bitar, M. (2014). Corporate Social Responsibility and Investment Efficiency. Financial Management Association European Conference (FMA), 7(9), 647-671.

Biddle, G. C., Hilary, G., \& Verdi, R. S. (2009). How Does Financial Reporting Quality Relate to Investment Efficiency? How Does Financial Reporting Quality Relate to Investment Efficiency? Abstract: Prior evidence that higher quality financial reporting improves capital investment efficiency. 
Journal of Accounting and Business, 48(2/3), 112-131.

Biddle, G., \& Hilary, G. (2006). Accounting Quality and Firm-level Capital Investment Department of Accounting Hong Kong University of Science and Technology Clear Water Bay, Kowloon. Hong Kong University of Science and Technology, 81(5), 963-982.

Chen, F., Hope, O., \& Wang, X. (2011). Financial Reporting Quality and Investment Efficiency of Private Firms in Emerging Markets Financial Reporting Quality and Investment Efficiency of Private Firms in Emerging Markets. The Accounting Review, 86(4), 1255-1288.

Dhaliwal, D. S., Li, O. Z., Tsang, A., \& Yang, Y. G. (2011). Voluntary Nonfinancial Disclosure and the Cost of Equity Capital: The Initiation of Corporate Social Responsibility Reporting. The Accounting Review, 86(1), 59-100. https://doi.org/10.2308/accr.00000005

Fuensanta, M., Gomariz, C., Pedro, J., \& Ballesta, S. (2014). Financial reporting quality, debt maturity and investment efficiency. Journal of Banking and Finance, 40(34), 494-496.

Gilaninia, \& Shahram. (2012). Financial Reporting Quality and Investment Efficiency of Iran. Interdiciplinary Journal of Contemporary Research In Business, 4(7), 218-222.

Hung, M., Shi, J., \& Wang, Y. (2013). The Effect of Mandatory CSR Disclosure on Information Asymmetry: Evidence from a Quasi-Natural Experiment in China. Asian Finance Association (AsFA), 7(1). https://doi.org/10.2139/ssrn.2206877

IAI. (2012). Ikatan Akuntansi Indonesia.

Jensen, M. C., \& Meckling, W. H. (1976). Theory of the Firm: Managerial Behavior, Agency Costs and Ownership Structure Theory of the Firm: Managerial Behavior, Agency Costs and Ownership Structure. Journal of Financial Economics, 4(3), 305-360.

Kangarlouei, S. ., Motayassel, Azizi, \& Faharani. (2011). The Investigation of The Relationship Between Financial Reporting Quality and Investment Efficiency in Tehran STock Exchange (TSE). Australian Journal of Basic and Applied Science, 5(12), 1165-1172.

Li, Q., \& Wang, T. (2010). Financial reporting quality and corporate investment efficiency: Chinese experience. Economics and Management, Wuhan University, 1(2), 197-213. https://doi.org/10.1108/20408741011052591 
Mcnichols, M. F., \& Stubben, S. R. (2014). Investment Decisions ? The Accounting Review, 85(2), 695-717. https://doi.org/10.2308/accr.2008.83.6.1571

Shehu, \& Hasan, U. (2012). Firm Characteristics and Financial Reporting Quality of Quoted Manufacturing Firm in Nigeria. Disertasi Ahmadu Bello University, Zaria Nigeria.

Tarigan, J., Semuel, H., Petra, U. K., \& Siwalankerto, J. (2014). Pengungkapan Sustainability Report dan Kinerja Keuangan. The Accounting Review, 16(2), 88-101. https://doi.org/10.9744/jak.16.2.88-101

Undang-undang Nomor 40 tahun 2007. (n.d.).

Verdi, R. S. (2006). Financial Reporting Quality and Investment Efficiency. Massachusetts Institute of Technology, 403(52), 702-707.

White, Sondi, \& Fried. (2003). The Analysis and Use of Financial Statements. (J. Wiley \& S. Inc, Eds.).

Wijayanti, R., \& Surakarta, U. M. (2016). Pengaruh Pengungkapan Sustainability Report Terhadap Kinerja Keuangan Perusahan. Fakultas Ekonomi Dan Bisnis, Universitas Muhammadiaayah Surakarta, 7(3), 39-51.

ZongMa, \& Gao, L. (2017). Does corporate social responsibility disclosure improve fi rm investment e ffi ciency? Journal of Accounting and Business, 7(3). https://doi.org/10.1108/RAF-06-2016-0095 